\title{
СУЧАСНІ ПРОБЛЕМИ ПРАВОВОГО ЗАБЕЗПЕЧЕННЯ СТЯГНЕННЯ АЛІМЕНТІВ
}

Січко Д. С.

\begin{abstract}
Статтю присвячено аналізу основних проблем правового забезпечення процесу стягнення аліментів на утримання дитини та практичним аспектам реалізаціі положень законодавства. Розкривається проблема законодавчого закріплення та обґрунтування способу стягнення аліментів. Розглядається логіка суду у виборі спо собів стягнення аліментів, що затверджують їх у твердій формі або у частиі до доходів особи. Проведено аналіз судової практики з проблеми стягнення аліментів за минулий період. Виокремлено основні аспекти та способи доказування особою свого права на стягнення таких аліментів в інтересах дитини, що склалися в процесі формування судової практики.
\end{abstract}

Ключові слова: аліменти, обов'язок утримання дитини, аліменти за минулий період, розмір аліментів, аліментні зобов'язання.

Статья посвящена анализу основных проблем правового обеспечения процесса взыскания алиментов на содержание ребенка и практическим аспектам реализации положений законодательства. Раскрывается проблема законодательного закрепления и обоснования способа взыскания алиментов. Рассматривается логика суда в выборе способов взыскания алиментов, которые утверждаются в твердой форме или в доле к доходам лица. Проведен анализ судебной практики по проблеме взыскания алиментов за прошедший период. Выделены основные аспекты и способы доказывания лицом своего права на взыскание таких алиментов в интересах ребенка, сложившиеся в процессе формирования судебной практики.

Ключевые слова: алименты, обязанность содержания ребенка, алименты за прошедший период, размер алиментов, алиментные обязательства.

Sichko D. S. Modern problems of legal support for alimony recovery

The research paper deals with the analysis of the main problems of legal support for the process of recovering alimony (child maintenance) and practical aspects of the implementation of the legislative provisions. First of all, the problem of providing a legislative framework for alimony recovery and substantiation of the method of recovering alimony is revealed. The logic of the court in choosing the methods of alimony recovery is considered while approving it in a fixed amount or in proportion to individual income. The latter is effective only provided the availability of official income of a person from whom such alimony is recovered. At the same time, in the absence of proven income, the most effective way is to establish a fixed amount of alimony. This clearly acts as an element of motivation for a person from whom alimony is recovered to find job, as well as the motive for legalization of income. Particular attention is paid to the analysis of the problem of alimony recovery from a person who departs to the place of permanent residence. It is established that existing mechanisms and methods of ensuring the practical fulfilment of alimony obligations in this case are reduced mainly

() Січко Д. С., 2020 to restrictive measures. The problem of obligation of employment of a person from whom the alimony is recovered and who does not have official proven income is objectively considered. The point of view that the state should create conditions for a person to realize his labour potential in order to obtain official income is maintained. A refusal or other means of avoiding such employment should be considered as a way of avoiding the fulfilment of alimony obligations. The analysis of legal regulation of alimony recovery for the past period was carried out. The main problems of the inaccuracy of legal structures and the lack of specification of the circumstances creating the prerequisites for the alimony recovery are revealed. The judicial practice on the alimony recovery for the past period was analyzed. The main aspects and ways of proving one's right to alimony in the interests of the child, formed in the course of judicial practice, are singled out.

Key words: alimony (child maintenance), child maintenance obligation, alimony for the past period, amount of alimony, alimony obligations.

Постановка проблеми та актуальність. Сімейні відносини, батьківство та виховання в сім'ї - це одні 3 найбільш визначальних цінностей, що формують сучасну національну самосвідомість українського народу. Традиції, пов'язані із сімейним вихованням та сімейними відносинами, мають надзвичайно міцні історичні корені, але в умовах сучасного суспільства вони зазнають значних змін та трансформацій, переважно негативного, руйнівного характеру. Ставиться під сумнів цілісність та непорушність сім'ї, що негативним чином впливає на процеси формування світоглядних орієнтирів нових поколінь. Все частіше батьки нехтують своїми обов' язками щодо дітей та свідомо створюють перешкоди на шляху їх всебічного та гармонійного розвитку, залишаючи сім'ї неповними. Крім такої морально-етичної проблеми, існує й інший, цілком практичний матеріальний вимір утримання дітей за рахунок аліментів батьків. Інститут аліментів стосується не лише утримання дітей, за рахунок аліментних платежів утримуються й інші категорії осіб, у тому числі недієздатні особи або навіть самі батьки за рахунок аліментів, що ї сплачують діти. Але саме відносини з приводу аліментів батьків на утримання їхніх неповнолітніх дітей $\epsilon$ найбільш гострими та актуальними для сучасної системи матеріального забезпечення дитинства, коли саме на етапі формування особистості вимагається найбільше уваги приділяти їі всебічному розвитку, в тому числі духовному, фізичному, морально-етичному, але це можливо лише за умови належного рівня матеріального забезпечення.

Аналіз останніх досліджень і публікацій. Проблематика стягнення аліментів на утримання дітей $є$ однією з найбільш гострих та актуальних, що підтверджується, зокрема, роботами М.В. Вербіцької, Т.В. Малярчук, 
Л.О. Самілик, Л.Я. Свистуна, Є. Ханович, О.С. Юніна та інших.

Мета статті - аналіз сучасних проблем правового забезпечення стягнення аліментів та пошук шляхів їх вирішення.

Виклад основного матеріалу. Інститут аліментів на утримання дитини батьками є одним із найбільш важливих не лише в практичній, але і в теоретико-методологічній площині. Саме по собі закріплення на законодавчому рівні обов'язку батьків утримувати дітей, в тому числі й за рахунок аліментів, не означає автоматичне підвищення або зміцнення матеріального та фінансового становища дитини. Більше того, сам інститут аліментів $\epsilon$ дієвою альтернативою в разі невиконання батьками своїх обов'язків щодо утримання дитини, навіть якщо такі батьки не бажають розривати шлюб, але живуть окремо від дитини. Держава опікується вихованням дітей, оскільки це генофонд нації, а тому результати процесу їх виховання в майбутньому екстраполюються на такі базові категорії національної самобутності, як право розуміння, правосвідомість, правова культура тощо. Тому держава зацікавлена закладати систему тих цінностей у світогляд дитини, яка $\epsilon$ бажаною для розвитку самої держави.

За таких обставин інститут аліментів $є$ важливим елементом відносин з приводу батьківства та формує самостійний комплекс відносин, що регулюється нормами сімейного законодавства. Держава, окрім гарантування права на аліменти, розуміючи низький рівень правової свідомості та правової культури осіб, які такі аліменти повинні сплачувати, розробляє спеціальні механізми та інструменти практичного характеру, спрямовані на забезпечення виконання аліментних зобов'язань перед дитиною. Хоча навіть за умови насичення національного законодавства нормативно-правовими актами, що передбачають стягнення аліментів, і навіть постійна їх актуалізація щодо розміру та величини аліментних зобов'язань, все одно існують об'єктивні проблеми їх невиконання. Частково їх вирішення $\epsilon$ об'єктивно ускладненим у силу існування тіньових процесів в економіці і недостатнім інструментарієм забезпечення легалізації доходів, отримуваних батьками для визначення коректної величини аліментів. Але $\epsilon$ проблеми, вирішення яких $є$ цілком можливим за рахунок встановлення або більш чітких правових конструкцій, або більш жорстких умов реалізації зобов'язань батьків із приводу утримання дитини.

Статтею 180 Сімейного кодексу України (далі - СК України) передбачено, що «батьки зобов'язані утримувати дитину до досягнення нею повноліття» [1]. Статтею 181 СК України регулюються способи виконання на практиці обов'язку з утримання дитини, причому в ч. 1 цієї статті зазначається, що їх вибір відбувається за домовленістю сторін, а у випадку, якщо такої домовленості не досягнуто, то порядок і способи виконання зобов'язання з утримання дитини визначаються в судовому порядку [1]. Це, власне, і $є$ аліментами відносини з приводу примусового виконання обов'язку одного з батьків щодо утримання дитини, визначеного в судовому порядку.

Відповідно до ч. 3 ст. 181 «за рішенням суду кошти на утримання дитини (аліменти) присуджуються у частці від доходу їі матері, батька або у твердій грошовій сумі за вибором того з батьків або інших законних представників дитини, разом з яким проживає дитина. Спосіб стягнення аліментів, визначений рішенням суду, змінюється за рішенням суду за позовом одержувача аліментів» [1]. Таким чином, дана норма визнає значно ширше коло прав у одержувача аліментів, ніж у особи, щодо якої прийнято рішення щодо їх стягнення в примусовому порядку. Для більш коректного сприйняття даної норми необхідно одразу звернути увагу на положення ч. 2 ст. 182 СК України, відповідно до якої «розмір аліментів має бути необхідним та достатнім для забезпечення гармонійного розвитку дитини. Мінімальний розмір аліментів на одну дитину не може бути меншим, ніж 50 відсотків прожиткового мінімуму для дитини відповідного віку» [1]. Даний розмір визначається з урахуванням відповідних положень бюджетного законодавства, а саме Законів України про Державний бюджет України на відповідний рік.

Системний аналіз наведених вище норм розкриває одну з найбільших проблем стягнення аліментів на утримання дитини - визначення реального розміру частки доходів одного з батьків, яку він повинен перераховувати як аліментні платежі на утримання дитини. Причому відповідно до ст. 181 СК України аліменти можуть визначатися як у твердій грошовій сумі, так і у частці від доходу, але ст. 183 СК України, деталізуючи порядок саме такого визначення аліментів, ототожнює поняття доходу та заробітку. Це $\epsilon$ наслідком керування в процесі стягнення аліментів положеннями Постанови Кабінету Міністрів України «Про перелік видів доходів, які враховуються при визначенні розміру аліментів на одного з подружжя, дітей, батьків, інших осіб» від 26.02.1993 р. № 146 [2], основна цінність якої сьогодні полягає лише в тому, що вона закріплює вичерпний перелік видів заробітку особи, з яких не стягуються аліменти. Що ж до видів заробітку (доходу), які враховуються у визначенні розміру аліментів, то тут слід керуватися положеннями п. 14.1.54 та п. 14.1.55 ч. 14.1. ст. 14 Податкового кодексу України, в яких визначається вичерпний перелік доходів з джерелом їх походження з України та поняття доходу, отриманого з джерел за межами України [3]. При цьому в незалежності від форми стягнення аліментів слід погодитися з думкою $€$. Ханович щодо існування недоліків в обох випадках: «недоліком визначення розміру аліментів у твердій грошовій сумі $\epsilon$ складна та недосконала процедура індексації аліментів і надзвичайна повільність реагування на збільшення або зменшення доходу боржника. Складність стягнення аліментів, визначених як частка доходу, полягає в тому, що особа, з якої ії стягують, часто приховує свій фактичний дохід, що $є$ досить розповсюдженою практикою в нашій країні» [4, с. 23-24]. Дана позиція $\epsilon$ слушною через недосконалість системи обліку та моніторингу доходів громадян, а також у силу того, що номінальна індексація грошових виплат відбувається по визначеним державою стандартам та нормативам, що досить часто не відповідає сучасним реаліям соціально-економічного становища.

Як зазначають Л.О. Самілик та Л.П. Корбут, «на практиці непогано опрацьований механізм встановлення реального доходу боржника-фізичної особи, зареєстрованої як індивідуальний підприємець. Набагато складніше визначати реальний дохід фізичної особи, що не має постійної роботи та іншого джерела доходу. Тим більше, що сам платник своїми діями може перешкод- 
жати виявленню реальної суми доходу» [5, с. 90-91]. Ця позиція $\epsilon$ надзвичайно слушною та цілком об'єктивною з урахуванням сучасних вітчизняних реалій, а тому потребує пошуку шляхів іï вирішення, причому не лише нормативно-правового, але й організаційного характеру. Зрозуміло, що питаннями примусового стягнення аліментів займаються органи, уповноважені на виконання судових рішень, зокрема Державної виконавчої служби України. Але важливим фактором $\epsilon$ також активна позиція особи, уповноваженої отримувати аліменти на утримання дитини, а також практика суду щодо вирішення способу встановлення величини аліментів. Так, на етапі судового розгляду справи необхідним $\epsilon$ встановлення джерел та розміру доходів особи, з якою стягуватимуться аліменти. Традиційно такі особи приховують реальні обсяги заробітку, але суд повинен встановити законні джерела їх отримання, а у випадку наявності неофіційного заробітку і відсутності офіційного повинен однозначно приймати рішення про встановлення аліментів у твердій формі.

Слід пам'ятати, що звернення до суду за аліментами $\epsilon$ правом особи, уповноваженої на їх отримання в інтересах неповнолітньої дитини у випадку, коли один із батьків не бере участь у вихованні та матеріальному забезпеченні дитини або ухиляється від утримання дитини. Тобто звернення до суду - це вже сам по собі елемент захисту такою особою порушеного права дитини, а тому доводи та будь-які докази особи, з якої стягуються аліменти, стосовно відсутності джерел доходів повинні розумітися судом як спосіб ії ухилення від виконання своїх батьківських зобов'язань. Ми жодним чином не розглядаємо аліменти як спосіб або міру відповідальності особи, що ухиляється від утримання дитини, але слід чітко усвідомлювати невідворотність виконання ним своїх батьківських обов'язків. Враховуючи будь-які обставини на користь одного з батьків щодо зменшення розміру аліментів або неможливості встановлення джерела доходів особи, яка їх приховує, суд у такому разі порушує права та зашкоджує інтересам дитини. Держава чітко гарантує необхідність не просто утримання дитини, але й створення належних умов для ії виховання. Щоправда, критерії належності відсутні в національному законодавстві, але цілком зрозуміло, що навіть не визначаючи їх, необхідно під час оцінки реального соціально-економічного становища в суспільстві визначати обсяг та величину аліментів на утримання дитини.

У цьому контексті слушною $\epsilon$ позиція Т.В. Малярчук та Х.К. Рогів, які вказують, що під час визначення розміру аліментів у твердій сумі суд може, користуючись аналогією права, встановлювати розмір аліментів, виходячи із витрат того з батьків, з ким проживає дитина, на іï утримання [6, с. 115-116]. Така позиція $\epsilon$ цілком слушною і до того ж вона повністю відповідає умовам доказування, оскільки, доказуючи розмір аліментів на дитину, сторона доказування надає відповідні чеки, платіжні документи, інші дані, які підтверджують фактичний розмір витрат на утримання дитини.

Крім того, наведена вище позиція дослідників цілком укладається в норми СК України. Так, відповідно до п. 32 та п. 4 ч. 1 ст. 182 СК України вказується, що «при визначенні розміру аліментів суд враховує доведені стягувачем аліментів витрати платника аліментів, у тому числі на придбання нерухомого або рухомого майна, сума яких перевищує десятикратний розмір прожиткового мінімуму для працездатної особи, якщо платником аліментів не доведено джерело походження коштів; інші обставини, що мають істотне значення» [1]. Наведені норми розширюють можливість для стягувача аліментів довести власну позицію та обґрунтувати розмір аліментів, які потрібні для утримання дитини. Але, на нашу думку, такий підхід законодавця щодо обов'язку доказування розміру витрат на дитину дещо принижує гідність дитини та того з батьків, хто їі утримує, і з ким вона проживає. Насправді утримувати дитину $\epsilon$ імперативом, визначеним на законодавчому рівні, а тому доказувати необхідність такого утримання $\epsilon$ недоцільним. Розмір аліментів, якщо він визначається у твердій сумі, повинен відповідати насамперед не можливостям боржника на момент судового розгляду, а потребам дитини. Суд не може враховувати небажання або ухиляння боржника від сплати аліментів за рахунок потреб дитини на утримання та розвиток. Ми розуміємо, що ця проблема має, скоріше, етичне походження, і моральний аспект цієї проблеми значно більший, ніж правовий, але, враховуючи неупередженість, законність та справедливість судового розгляду, все ж мати на увазі права боржника. Саме тому ми наполягаємо на тому, що у випадку відсутності офіційних джерел доходів боржника або ухиляння ним від сплати аліментів вони повинні встановлюватися у твердій грошовій сумі, а їх величина не може дорівнювати величині доведених у суді стягувачем розміру витрат на дитину за минулий період, хоча б з тих міркувань, що в майбутньому відбуваються об'єктивні інфляційні процеси, а розмір потреб дитини постійно зростає.

У випадку ухвалення рішення суду щодо стягнення аліментів у твердій сумі боржник завжди може і повинен у ситуації, коли він доводить відсутність офіційних доходів, скористатися послугами Державної служби зайнятості. Остання повинна здійснювати не лише виплати по безробіттю такій особі, а здійснювати пошук роботи з високим рівнем заробітної плати, а у випадку відмови особи влаштуватися на таку роботу повідомити правоохоронні органи та органи у справах дітей щодо такого рішення особи. На нашу думку, враховуючи порядок та механізм пошуку роботи безробітним в органах Державної служби зайнятості, ми повинні розуміти, що такій особі пропонуватиметься максимально підходяща робота, критерії та визначення якої встановлюється законодавством України у сфері зайнятості, а тому відмова без поважних причин від неї за умови існування судового рішення щодо стягнення аліментів на користь дитини повинна розглядатися як ухилення від виконання такого рішення.

О.С. Юнін зазначає, що «виховання та матеріальне утримання дітей $є$ одним із найголовніших та найважливіших обов'язків батьків, що випливає не тільки з усталених моральних принципів нашого суспільства, а й закріплено в нормах чинного законодавства. При цьому аліменти виступають одним з основних засобів забезпечення дитини матеріальними благами, що необхідні їй для повноцінного розвитку та виховання» [7, с. 137-138]. Саме цим науковець обґрунтовує необхідність постійного підвищення уваги до проблеми кримінальної відповідальності за несплату або ухилення від уплати аліментів особами, щодо яких такий обов'язок присуджений у судовому порядку. Поділяючи пози- 
цію дослідника, ми акцентуємо увагу на тому, що під час визначення об'єктивної сторони злочину ухилення або злісного ухилення від уплати аліментів необхідно брати до уваги будь-які обставини, які свідчать про небажання особи знаходити та користуватися можливостями, які б суттєво розширили їі матеріальне становище. За таких обставин вбачається можливим боротися з неофіційними доходами таких осіб, легалізуючи ïх та визначаючи реальний обсяг аліментів або реальну фінансову спроможність особи утримувати дитину. Таку саме позицію щодо прийняття до уваги всіх без виключення обставин поведінки особи, яка приховує свої неофіційні доходи, але ухиляється від отримання доходів офіційних, повинен займати й суд, визначаючи розмір аліментів у твердій сумі.

Таким чином, нами обстоюється позиція щодо необхідності уточнення ч. 3 ст. 181 СК України та викладення їі в такій редакції:

«За рішенням суду кошти на утримання дитини (аліменти) присуджуються у частці від доходу їі матері, батька або у твердій грошовій сумі за вибором того з батьків або інших законних представників дитини, разом з яким проживає дитина, у випадку якщо відомі доведені доходи того з батьків, кому присуджується сплата аліментів, перевищують розмір, указаний у частині третій статті 184 цього Кодексу.

У разі якщо той з батьків, якому присуджується сплата аліментів на утримання дитини, не має доведених доходів, розмір аліментів визначається на підставі судового наказу у твердій грошовій сумі в розмірі, що не може бути меншим, ніж вказаний у частині третій статті 184 цього Кодексу.

Спосіб стягнення аліментів, визначений рішенням суду, змінюється за рішенням суду за позовом одержувача аліментів».

Таким чином, нами пропонується закріпити саме в такій редакції ч. 32 ст. 181 СК України, що, на нашу думку, стане елементом суттєвої мотивації для того з батьків, хто приховує свої офіційні доходи, розкрити їх.

На сучасному етапі розвитку суспільних процесів відмічається зростання міграційних процесів в Україні, що призводить до масового виїзду за кордон громадян України на заробітки та породжує проблему стягнення аліментів 3-за кордону. Відповідно до ч. 4-6 ст. 181 СК України законодавець намагається певним чином цю проблему розв'язати, закріплюючи, зокрема, що «у разі виїзду одного з батьків за кордон на постійне проживання в державу, з якою Україна не має договору про надання правової допомоги, аліменти стягуються в порядку, встановленому Кабінетом Міністрів України» [1]. Йдеться про Порядок стягнення аліментів на дитину (дітей) у разі виїзду одного з батьків для постійного проживання в іноземній державі, з якою не укладено договір про подання правової допомоги, затверджений Постановою Кабінету Міністрів України від 19 серпня 2002 р. № 1203 [8], відповідно до якого основними засобами забезпечення права дитини на отримання аліментів виступають: заборона у видачі виїзних документів за кордон; обмеження виїзду або в інший спосіб обмеження можливостей потрапляння в країну. в яку особа виїжджає. Щоправда, до такого виїзду передбачається, що особа «повинна виконати аліментні зобов'язання з утримання дитини (дітей) до досягнення нею повноліття, які оформляються договором між цією особою та одним із батьків, з яким залишається дитина (діти), або іï опікуном, піклувальником, або договором про припинення права на аліменти для дитини (дітей) у зв'язку з передачею права власності на нерухоме майно» [8]. Хоча, загалом, як стверджує Л.Я. Свистун, проблема стягнення з особи, яка виїжджає за кордон, «полягає насамперед в істотних відмінностях у матеріально-правових та процесуальних нормах сімейного права, що є причиною виникнення колізій під час виконання рішення іноземного суду. Зокрема, коли дитина проживає на території однієї країни і судом цієї ж країни ухвалено рішення про стягнення аліментів на їі користь, а боржник проживає на території іншої країни» [9, с. 86]. Хоча дана проблема вирішується Міністерством юстиції України шляхом видання Наказу «Про затвердження Інструкції про виконання в Україні Конвенції про міжнародне стягнення аліментів на дітей та інших видів сімейного утримання» від 15.09.2017 р. № 2904/5 [10], але цей наказ не містить жодних більш дієвих механізмів притягнення особи до відповідальності у випадку ухилення від сплати аліментів або приховування власного доходу, ніж звернення до суду.

Розуміючи, що звернення до суду $\epsilon$ одним з основних способів захисту прав дитини, ми цілком підтримуємо позицію, викладену в Наказі, але акцентуємо увагу на тому, що виконання аліментів повинно здійснюватися до виїзду такої особи за кордон, у випадку, якщо вони виникли до виїзду. Причому в разі отримання особою громадянства іншої держави або права на тимчасове/постійне проживання приймаюча сторона і консульські відділи такої держави повинні бути повідомлені про наявність невиконаних аліментних зобов'язань у такої особи.

Досить цікавою та, на наш погляд, важливою нормою з точки зору повноти забезпечення утримання дитини $\epsilon$ положення ч. 1 ст. 194, відповідно до якої «аліменти можуть бути стягнуті за виконавчим листом за минулий час, але не більш як за десять років, що передували пред'явленню виконавчого листа до виконання» [1]. Отже, право на стягнення аліментів за минулий час виникає у відповідності до ч. 1 ст. 194 СК України та не містить жодних обмежень або умов реалізації, окрім таких:

обов'язкова наявність виконавчого листа;

- строк обмежується 10-ю роками від дати пред'явлення виконавчого листа до виконання.

Водночас процедурні аспекти реалізації права на аліменти за минулий період визначаються в ч. 2 ст. 191 СК України, відповідно до якої «аліменти за минулий час можуть бути присуджені, якщо позивач подасть суду докази того, що він вживав заходів щодо одержання аліментів з відповідача, але не міг їх одержати у зв' язку з ухиленням останнього від їх сплати. У цьому разі суд може присудити аліменти за минулий час, але не більш як за десять років» [1]. Але судова практика демонструє наявність переважно відмов судових інстанцій у реалізації права на стягнення аліментів за минулий період.

Із цього приводу М.В. Вербицька зазначає, що така ситуація «зумовлена тим, що для призначення стягнення аліментів за минулий час позивач повинен подати суду докази того, що він вживав заходи щодо одержання аліментів з відповідача, але не міг їх одержати у зв'язку з ухиленням останнього від їх сплати. Тобто вважається 
недоцільним обтяжувати відповідача виплатами за минулий період, якщо позивач не вживав заходів щодо одержання аліментів (у тому числі не подавав позов про стягнення аліментів) з особистих мотивів. Припускається, що особа, добровільно беручи на себе повністю тягар з утримання дитини, передбачає пов'язані з цим складнощі й готова їх долати самостійно» [11, с. 33-34]. Погоджуючись із, можливо, саме такою логікою судів у вирішенні питання стягнення аліментів за минулий час, вважаємо за необхідне звернути увагу на те, що сучасна практика вже виробила певні підходи до вирішення проблеми доказування вжиття заходів особою, яка звертається за такими аліментами, та доказування фактів ухилення від виконання обов'язку з утримання особою, яка $є$ відповідачем у судовому спорі з цієї проблематики.

Дійсно, законодавець не дає чіткого розуміння порядку стягнення аліментів за минулий час, але відповідь на це питання дає сучасна усталена судова практика.

Так, наприклад, Апеляційним судом Одеської області в межах провадження по справі № 500/1567/16-ц в Постанові від 05.03.2018 року робиться висновок стосовно прямої дії норми про стягнення аліментів за минулий час, але не більше як за три роки (редакція СК України до 03.07.2018 року), що передували пред'явленню виконавчого листа до виконання. Тобто це право не потребує додаткового визнання в судовому порядку, а підлягає реалізації через звернення до виконавчої служби [12].

Харківський апеляційний суд у Постанові від 04.02.2019 року у справі № 640/15525/18 робить висновок, що відповідно до ч. 2 ст. 191 СК України аліменти за минулий час можуть бути присуджені, якщо позивач подасть суду докази того, що він вживав заходів щодо одержання аліментів з відповідача, але не міг їх одержати у зв'язку з ухиленням останнього від їх сплати [13]. За змістом цієї норми права стягнення аліментів за час, що передує пред'явленню позову, $\epsilon$ можливим у порядку виключення лише за наявності таких умов:

- до моменту звернення з позовом до суду аліменти не стягувались;

особа, яка вимагає аліментів, приймала заходи щодо одержання аліментів, але вони не були одержані в результаті ухилення особи від виконання обов'язку з утримання дитини.

Щодо необхідності доведення фактів ухилення від виконання обов'язку з утримання дитини судова практика засвідчує, що ухилення може вважатися винною протиправною поведінкою, тобто це свідоме невиконання своїх обов' язків в умовах, коли позивач звертався до відповідача особисто або в інший спосіб про сплату грошової суми, необхідної для утримання дитини. Таким чином, для вирішення справи по суті на користь позивача необхідним $є$ подання до суду доказів: вжиття заходів щодо одержання аліментів з відповідача; ухилення відповідача від надання утримання. Дана позиція викладена в Постанові Київського апеляційного суду від 28.11.2018 року у справі № 369/4847/18 [14].

Вітчизняне законодавство не визначає, які саме заходи має вжити позивач для звернення до відповідача в позасудовому порядку щодо утримання своєї дитини. Натомість судова практика, зокрема Львівський апеляційний суд у Постанові від 14.02.2019 року у справі
№ 454/2008/18 зазначає, що такими заходами можуть бути: звернення позивача до відповідача; звернення позивача до будь-яких державних органів за отриманням аліментів [15].

Як відзначається в судовій практиці, зокрема в Постанові Харківського апеляційного суду від 04.02.2019 року у справі № 640/15525/18, Постанові Київського апеляційного суду від 28.11.2018 року у справі № 369/4847/18, ухилення особи може виражатися в тому, що зобов'язана особа-відповідач: ухилявся від укладення договору про сплату аліментів на утримання дитини, приховував своє місцезнаходження або свій заробіток (доходи), вчиняв інші дії, що свідчать про відсутність доброї волі сплачувати аліменти на утримання дитини [13; 14]. Таким чином, відмічаємо, що сучасна судова практика значно деталізує способи реалізації права на стягнення аліментів за минулий період, що закріплено в законодавстві, та робить його більш утилітарним.

Висновки. Аналізуючи сучасні проблеми реалізації права на аліменти на утримання дитини, зазначимо таке. Головним джерелом таких проблем $\epsilon$ відсутність дієвих механізмів примушення особи виконувати батьківський обов'язок щодо утримання дитини. Стягнення аліментів у судовому порядку пов'язане з обов'язком доведення особою, яка звертається до суду, можливості відповідача аліменти сплачувати, а також власне розміру таких аліментів. Натомість якщо особа не має офіційних доходів, то суд, ураховуючи цю обставину як фінансову неспроможність відповідача, може суттєво зменшити розмір аліментів, які зазначаються позивачем. Так само на позивача лягає тягар доказування ухилення особи від виконання обов'язку утримання дитини у випадку стягнення аліментів за минулий період. Такий підхід судів $є$ цілком обґрунтованим та вкладається в принципи законності, неупередженості та об'єктивності судового розгляду правового конфлікту. Однак необхідно усвідомлювати, що обов'язок утримувати дитину $є$ об'єктивним і не може бути зменшений чи змінений за жодних обставин, а батьки повинні шукати можливості для його виконання. Саме цим пояснюються пропозиції до уточнення законодавства, а також точка зору щодо необхідності керуватися судам під час визначення способу стягнення аліментів не лише реальним рівнем доходів відповідача, але і зростаючими потребами дитини.

\section{Література}

1. Сімейний кодекс України : Кодекс України від 10.01.2002 р. № 2947-III. URL: https://zakon.rada.gov.ua/ laws/show/2947-14 (дата звернення: 17.03.2020).

2. Про перелік видів доходів, які враховуються при визначенні розміру аліментів на одного з подружжя, дітей, батьків, інших осіб : Постанова Кабінету Міністрів України від 26.02.1993 р. № 146. URL: https://zakon.rada.gov.ua/ laws/show/146-93-п (дата звернення: 17.03.2020).

3. Податковий кодекс України : Кодекс України від 02.12.2010 р. № 2755-VI. URL: https://zakon.rada.gov.ua/ laws/show/2755-17\#n256 (дата звернення: 17.03.2020).

4. Ханович $€$. Порядок стягнення аліментів на дитину за чинним законодавством. Підприємництво, господарство і право. 2016. № 10. С. 20-25.

5. Самілик Л.О., Корбут Л.П. Проблеми забезпечення належного виконання зобов'язань зі сплати аліментів. Порівняльно-аналітичне право. 2015. № 6. С. 90-92. 


\section{Проблеми цивільного та господарського права}

6. Малярчук Т.В., Рогів Х.К. Актуальні проблеми сплати аліментів дітям і можливі шляхи їх подолання. Сучасні питання економіки і права. 2013. Вип. 2. С. 113-118.

7. Юнін О.С. Стягнення заборгованості по аліментах та притягнення боржника до відповідальності за невиконання аліментних обов'язків: проблеми теорії та практики. Науковий вісник Дніпропетровського державного університету внутрішніх справ. Дніпропетровськ, 2017. № 1. С. 132-139.

8. Про затвердження Порядку стягнення аліментів на дитину (дітей) у разі виїзду одного з батьків для постійного проживання в іноземній державі, з якою не укладено договір про подання правової допомоги : Постанова Кабінету Міністрів України від 19.08. 2002 р. № 1203. URL: https://zakon.rada.gov.ua/laws/show/1203-2002-п (дата звернення: 17.03.2020).

9. Свистун Л.Я. Правове регулювання стягнення аліментів на дітей. Право і суспільство. 2018. № 1. С. 88-94.

10. Про затвердження Інструкції про виконання в Україні Конвенції про міжнародне стягнення аліментів на дітей та інших видів сімейного утримання : Наказ Міністерства юстиції України ; Інструкція від 15.09.2017 р. № 2904/5. URL: https://zakon.rada.gov.ua/laws/show/z1150-17 (дата звернення: 17.03.2020).

11. Вербіцька М.В. Актуальні проблеми стягнення аліментів на неповнолітніх дітей. Науковий вісник Ужгород-
Ського національного університету. Сер. Право. Ужгород, 2012. Т. 2. Вип. 20. Ч. 1. С. 32-36.

12. Постанова Апеляційного суду Одеської області по справі №500/1567/16-ц від 05.03.2018 p. URL: http:// www.reyestr.court.gov.ua/Review/72751004 (дата звернення: 17.03.200).

13. Постанова Харківського апеляційного суду у справі № 640/15525/18 від 04.02.2019 року. URL: http:// www.reyestr.court.gov.ua/Review/79599163 (дата звернення: 17.03.2020).

14. Постанова Київського апеляційного суду у справі №369/4847/18 від 28.11.2018 р. URL: http:// www.reyestr.court.gov.ua/Review/78244499 (дата звернення: 17.03.2020).

15. Постанова Львівського апеляційного суду у справі № № 454/2008/18 від 14.02.2019 p. URL: http:// www.reyestr.court.gov.ua/Review/79859891 (дата звернення: 17.03.2020).

Січко Д. С., кандидат юридичних наук, доцент, доцент кафедри цивільного та кримінального права i npouecy Чорноморського національного університету імені Петра Могили 